\title{
KOMPETENSI GURU DALAM MELAKSANAKAN DAN MENGELOLA PROSES BELAJAR MENGAJAR DI PONDOK PESANTREN DARUL MURSYIDI DESA SIALOGO TAPANULI SELATAN
}

\author{
Darliana Sormin \\ Dosen Universitas Muhammadiah Tapanuli Selatan, Padangsidimpuan. \\ Jl. Sutan Muhammad Arief No. 32, Padangsidimpuan, Sumatera Utara \\ Email: anamuthmainnah82@gmail.com
}

\begin{abstract}
This study discusses the competence of teachers in implementing and managing learning in Pon-pes Darul Mursyidi. The purposes of this study were to determine the competence of teachers in managing learning in Pon-pes Darul Mursyidi and to know the efforts of teachers in managing learning in Pon-pes Darul Mursyidi. The research method used is descriptive qualitative method while the data collection techniques used were interviews, observation and documentation, and the analysis of data by compiling the data, organizing the data, then describing systematically. The results of the competency of teachers in implementing and managing learning in Pon-pes Darul Mursyidi've started well although still have problems, all the planning and implementation process of learning have applied maximally by teachers at Darul Ponpes Mursyidi. Then, the efforts are being made in the establishment of the competency of teachers by suggesting continuing education to a higher level, following the seminars, training, or workshops, and reading relevant books to broaden the knowledge and competence.
\end{abstract}

Keyword: Teacher Competence, Implement, Manage, Learning

\begin{abstract}
Abstrak
Penelitian ini membahas tentang kompetensi guru dalam melaksanakan dan mengelola pembelajaran di Pon-pes Darul Mursyidi. Tujuan penelitian ini adalah untuk mengetahui bagaimana kompetensi guru dalam mengelola pembelajaran di Pon-pes Darul Mursyidi dan Untuk mengetahui apa saja upaya guru dalam mengelola pembelajaran di Pon-pes Darul Mursyidi. Adapun metode penelitian yang digunakan adalah metode kualitatif deskriptif sedangkan teknik pengumpulan data yang digunakan adalah wawancara, observasi dan dokumentasi, sedangkan analisa data dengan menyusun data, mengola data, kemudian mendeskripsikannya secara sistematis. Hasil kompetensi guru dalam melaksanakan dan mengelola pembelajaran di Pon-pes Darul Mursyidi sudah mulai baik walaupun masih bayak kendala, semua proses perencanaan dan pelaksanaan pembelajaran sudah mulai maksimal diterapkan oleh guru di Ponpes Darul Mursyidi. Upaya yang dilakukan dalam pembentukan kompetensi guru dengan menyarankan melanjutkan pendidikan ke jenjang yang lebih tinggi, mengikuti
\end{abstract}


seminar atau pelatihan, mengikuti penataran loka karya, membaca buku yang relevan untuk menambah wawasan keilmuan.

Kata kunci: Kompetensi Guru, Melaksanakan, Mengelola, Belajar Mengajar

\section{PENDAHULUAN}

\section{Latar Belakang}

Pendididikan merupakan interaksi antara orang dewasa dengan orang yang belum dapat menunjang perkembangan manusia yang ber orientasi pada nilai-nilai dan pelestarian serta perkembangan kebudayaan yang berhubungan dengan usaha pengembangan kehidupan manusia.

Dewasa ini pendidikan berkembang semakin pesat dan semakin kompleks, persoalan pendidikan yang dihadapi bukanlah tantangan yang dibiarkan begitu saja, akan tetapi memerlukan pemikiran yang konstruktif demi tercapainya kualitas tujuan pendidikan yang baik. Persoalan yang dimaksud diantaranya adalah kompetensi mengajar guru karena guru sebagai orang yang berhubungan langsung dengan peserta didik seharusnya mempunyai kompetensi yang baik dalam pelaksanaan proses belajarmengajar.

Dalam Peraturan Menteri Pendidikan Nasional RI Nomor 16 Tahun 2007 tentang Standar Kompetensi Akademik dan Kompetensi Guru dijelaskan bahwa: Kualifikasi Akademik guru SD/MI, SMP/MTs, dan SMA/MA minimum diploma empat (D-4) atau sarjana (S-1). Dalam Penjamin Mutu Pendidikan Nasional (PMPN) ini juga disebutkan bahwa: Guru harus menguasai empat kompetensi utama, yaitu pedagogis, kepribadian, sosial, dan profesional. Keempat kompetensi ini terintegrasi dalam kinerja guru. ${ }^{1}$

Sehubungan dengan hal tersebut Syaiful Bahri Djamarah menyatakan bahwa: Guru sebagai orang yang bertanggung jawab terhadap pendidikan, baik secara individual maupun secara klasikal, baik di sekolah maupun di luar sekolah minimal harus memiliki dasar-dasar kompetensi dalam menjalankan tugasnya. ${ }^{2}$

Seorang guru harus memiliki kepribadian, menguasai bahan pelajaran dan cara-cara mengajar sebagai kompetensinya. Tanpa hal tersebut guru akan gagal dalam melaksanakan tugasnya sebagai seorang pendidik. Karena kompetensi mengajar harus dimiliki oleh seorang guru dalam mengelola kegiatan belajar-mengajar.

Dalam rangka meningkatkan mutu pendidikan, guru mempunyai peranan yang sangat penting dalam merealisasikan tujuan pendidikan. Guru adalah ujung tombak kegiatan pengajaran di sekolah yang langsung berhadapan dengan siswa, maka tanpa

\footnotetext{
${ }^{1}$ Jejen Musfah, Peningkatan Kompetensi Guru (Jakarta: Kencana Prenada Media Group, 2012), hal. 3-4

2 Syaiful Bahri Djamarah, Prestasi Belajar dan Kompetensi Mengajar (Surabaya: Usaha Nasional, 1991), hal.
} 
adanya peranan guru kegiatan belajar-mengajar tidak bisa berjalan dengan baik. Mengajar bukanlah kegiatan yang mudah melainkan suatu kegiatan dan tugas yang berat, penuh dengan masalah, dan penuh tanggung jawab. Kemampuan dan kecakapan sangat dituntut bagi seorang guru. Karena itu seorang guru harus memiliki kecakapan dan keahlian tentang keguruan. Kemampuan dan kecakapan merupakan modal dasar bagi seorang guru dalam melakukan tugasnya.

Mengajar adalah mengorganisasikan aktivitas siswa dalam arti yang luas. Peran guru bukan semata-mata memberikan informasi, melainkan juga mengarahkan dan memberi fasilitas belajar agar proses belajar lebih memadai. Perencanaan pengajaran, pelaksanaan kegiatan belajar-mengajar dan kegiatan evaluasi pengajaran, merupakan serangkaian kegiatan dalam mengelola pembelajaran yang dikuasai dan dimiliki oleh seorang guru adalah merupakan bagian dari kompetensi guru itu sendiri. Beranjak dari kompetensi inilah guru akan mengetahui apa yang harus dijalankannya, baik dalam perencanaan, pelaksanaan maupun evaluasi berdasarkan teori yang diperoleh dari lembaga pendidikan yang pernah ditempuhnya. Oleh karena itu, kompetensi suatu yang mutlak dimiliki oleh setiap guru yang mempunyai kompetensi mengajar yang baik dalam proses pembelajaran tidaklah mudah ditemukan, disamping itu kompetensi mengajar guru bukanlah persoalan yang berdiri sendiri tetapi dipengaruhi oleh faktor lain, di antaranya faktor latar belakang pendidikan, pengalaman mengajar dan training keguruan yang pernah diikuti. Dengan demikian guru yang mempunyai kompetensi mengajar akan mampu menciptakan lingkungan belajar yang efektif, efesien, dan menyenangkan serta akan lebih mampu mengelola kelasnya sehingga hasil belajar siswa berada pada tingkat optimal. Disamping hal tersebut, kompetensi dalam proses interaksi belajar-mengajar dapat pula menjadi alat motivasi ekstrinsik, guna memberikan dorongan dari luar diri siswa. ${ }^{3}$

Berdasarkan observasi awal di Pondok Pesantren (Pon-pes) Darul Mursyidi dengan guru ketika mengajar, peneliti melihat guru sudah mempersiapkan perencanaan pembelajaran dan pelaksanaan proses pembelajaran, walaupun masih belum maksimal dalam pengelolaannya. ${ }^{4} \mathrm{Hal}$ ini terlihat ketika guru mengajar, seperti kurangnya guru untuk melibatkan siswa secara aktif dalam proses pembelajaran dan kurang dalam memberikan kesimpulan dari materi yang dibahas, sehingga banyak siswa yang pasif dan kurang menguasai pelajaran.

Maka, mengingat pentingnya peningkatan kompetensi guru, sehingga guru diharapkan dapat meningkatkan kemampuan mengajar. Dalam usaha ini banyak cara yang dapat dilakukan, seperti menggunakan metode mengajar yang bervariasi, memberikan penghargaan kepada siswa yang berprestasi, dan lain-lain. Dampak dari

\footnotetext{
${ }^{3}$ Syaiful Bahri Djamarah Op.Cit, hal. 34

4 Bapak Zubeir, Guru Al- Qur'an Hadist Observasi tanggal 01 April 2015
} 
tidak ditingkatkannya kompetensi guru akan mengakibatkan proses pembelajaran yang monoton dan membosankan.

\section{Tujuan Penelitian}

Adapun tujuan penelitian ini yaitu :

a. Untuk mengetahui kompetensi guru dalam melaksanakan dan mengelola pembelajaran di Pon-pes Darul Mursyidi.

b. Untuk mengetahui upaya guru dalam melaksanakan dan mengelola pembelajaran di Pon-pes Darul Mursyidi.

\section{KAJIAN TEORI}

\section{Pengertian Kompetensi Guru}

Menurut UU Republik Indonesia (RI) Nomor 14 Tahun 2005 menyatakan bahwa kompetensi adalah seperangkat pengetahuan, keterampilan, dan perilaku yang harus dimiliki, dihayati, dan dikuasai oleh guru atau dosen dalam melaksanakan tugas keprofesionalan. ${ }^{5}$

Kompetensi guru menurut Peraturan Pemerintah (PP) No. 19 Tahun 2005 tentang Standar Nasional Pendidikan, pemerintah telah merumuskan empat jenis kompetensi guru, adalah sebagai berikut: ${ }^{6}$

a. Kompetensi Pedagogik, yaitu merupakan Kemampuan dalam pengelolaan peserta didik yang meliputi; a) pemahaman wawasan atau landasan kependidikan; b) pemahaman terhadap peserta didik; c) pengembangan kurikulum/silabus; d) perancangan pembelajaran; e) pelakanaan pembelajaran yang mendidik dan dialogis; f) evaluasi hasil belajar; dan g) pengembangan peserta didik untuk mengaktualisasikan berbagai potensi yang dimilikya.

b. Kompetensi Kepribadian, yaitu Kemampuan kepribadian yang: a) berakhlak mulia; b) mantap, stabil, dan dewasa; c) arif dan bijaksana; d) menjadi teladan; e) mengavaluasi kinerja sendiri; f) mengembangkan diri; dan g) religius.

c. Kompetensi Sosial merupakan kemampuan pendidik sebagai bagian dari masyarakat untuk: a) berkomunikasi lisan dan tulisan; b) menggunakan teknologi komunikasi dan informasi secara fungsional; c) bergaul secara efektif dengan peserta didik, sesama pendidik, tenaga kependidikan, orangtua/wali peserta didik; dan d) bergaul secara santun dengan masyarakat sekitar.

d. Kompetensi Profesional yaitu kemampuan penguasaan materi pembelajaran secara luas dan mendalam yang meliputi: a) konsep, struktur, dan metode keilmuan/teknologi/seni yang menaungi/koheren dengan materi ajar; b) materi ajar

\footnotetext{
${ }^{5}$ Undang-Undang Republik Indonesia, Nomor. 14 Tahun 2005, Tentang Guru dan Dosen, Bab I Pasal 1 Ayat 10 (Jakarta: Sinar Grafika, 2006), hal. 3

${ }^{6}$ Ibid, hal. 30-54
} 
yang ada dalam kurikulum sekolah; c) hubungan konsep antarmata pelajaran terkait; d) penerapan konsep keilmuan dalam kehidupan sehari-hari; dan e) kompetisi secara profesional dalam konteks global dengan tetap melestarikan nilai dan budaya nasional.

Kompetensi berarti kecakapan, kemampuan dan wewenang. ${ }^{7}$ Seseorang dinyatakan berkompetensi dibidang tertentu jika menguasai kecakapan bekerja sebagai suatu keahlian selaras dengan bidangnya. Kompetensi menunjuk kepada performance dan perbuatan yang rasional untuk memenuhi spesifikasi tertentu dalam melaksanakan tugas-tugas kependidikan. Di katakan rasional karena mempunyai arah dan tujuan, performance merupakan prilaku nyata dalam arti tidak hanya diamati, tetapi juga meliputi prihal yang tidak tampak.

Menurut Spencer dalam buku B.Uno membagi lima karakteristik kompetensi sebagai berikut: ${ }^{2}$

a. Motif, yaitu suatu yang dipikirkan dan diinginkan yang menyebabkan sesuatu.

b. Sifat, yaitu karakteristik fisik tanggapan konsisten terhadap situasi atau informasi.

c. Konsep, yaitu sikap, nilai, dan image dari seseorang.

d. Pengetahuan, yaitu informasi yang dimiliki seseorang dalam bidang tertentu.

e. Keterampilan, yaitu kemampuan untuk melakukan tugas-tugas yang berkaitan dengan fisik dan mental.

Setelah membahas tentang teori kompetensi di atas, selanjutnya apa yang disebut dengan kompetensi guru? Kompetensi guru adalah salah satu faktor yang mempenggaruhi tercapainya tujuan pembelajaran dan pendidikan di sekolah, namun kompetensi guru tidak berdiri sendiri, tetapi dipengaruhi oleh faktor latar belakang pendidikan, pengalaman belajar, dan lamanya mengajar. Kompetensi guru dapat dinilai penting sebagai alat seleksi dalam penerimaan calon guru, juga dijadikan sebagai pedoman dalam rangka pembinaan dan pengembangan tenaga guru, selain itu juga, penting dalam hubungannya dengan kegiatan belajar dan hasil belajar siswa.

Menurut M. Amin yang dikutip dari Hamzah: Kompetensi guru pada hakikatnya tidak lepas dari konsep hakikat guru dan hakikat tugas guru. ${ }^{9}$ Kompetensi guru mencerminkan tugas dan kewajiban guru yang harus dilakukan sehubungan dengan arti jabatan guru yang menuntut suatu kompetensi tertentu. Ace Suryadi mengemukakan bahwa untuk mencapai taraf kompetensi, seorang guru memerlukan waktu lama dan biaya mahal. Status kompetensi yang profesional tidak diberikan oleh siapapun, tetapi harus dicapai dalam kelompok profesi yang bersangkutan. Awalnya,

${ }^{7}$ Djama'an Satori, Sunaryo Kardinata, dkk, Profesi Keguruan I (Jakarta: Universitas Terbuka 2002), hal.

${ }^{8}$ Hamzah B. Uno, Profesi Kependidikan (Jakarta: PT Bumi Aksara, 2008), hal. 63

${ }^{9}$ Ibid., hal. 64 
tentu, harus dibina melalui penguatan landasan profesi, misalnya pembinaan tenaga kependidikan, yang sesuai, pengembangan infrastruktur, pelatihan jabatan yang memadai, efesiensi dalam sistem perencanaan, serta pembinaan administrasi dan pembinaan kepegawaian. ${ }^{10}$

Kompetensi guru profesional menurut pakar pendidikan seperti Soediarto menuntut dirinya sebagai seorang guru agar mampu menganalisis, mendiagnosis, dan memprognosis situasi pendidikan. Guru yang memiliki kompetensi profesional perlu menguasai antara lain: ${ }^{11}$

a. Disiplin ilmu pengetahuan sebagai sumber bahan pelajaran.

b. Bahan ajar yang diajarkan.

c. Pengetahuan tentang karakteristik siswa.

d. Pengetahuan tentang filsafat dan tujuan pendidikan.

e. Pengetahuan serta penguasaan metode dan model mengajar.

f. Penguasaan terhadap prinsip-prinsip teknologi pembelajaran.

g. Pengetahuan terhadap penilaian dan mampu merencanakan, memimpin untuk kelancaran proses pendidikan.

Tuntutan atas berbagai kompetensi ini mendorong guru untuk memperoleh informasi yang dapat memperkaya kemampuan agar tidak mengalami ketinggalan dalam kompetensi profesionalnya. Semua hal yang disebutkan di atas merupakan halhal yang dapat menunjang terbentuknya kompetensi profesional guru. Dengan kompetensi profesional tersebut, dapat diduga berpengaruh pada proses pengelolaan pendidikan sehingga mampu melahirkan bentuk pendidikan yang bermutu. Produk yang bermutu dapat dilihat pada hasil langsung, pendidikan yang berupa nilai yang dicapai siswa dan dapat juga dilihat melalui dampak pengiring, yakni dimasyarakat. Sebab diantara yang berpengaruh pada pendidikan antara lain adalah komponen input. Proses, dan keluaran pendidikan serta berbagai sistem lain yang berkembang dimasyarakat.

\section{Macam-macam Kompetensi}

Kompetensi guru merupakan gambaran hakikat kualitatif dari prilaku guru atau tenaga kependidikan yang tampak sangat berarti. ${ }^{12}$ Prilaku disini bukan hanya merujuk pada prilaku nyata, tetapi juga meliputi hal-hal yang tidak tampak.

${ }^{10}$ Ace Suryadi, Pendidikan Investasi SDM dan Pengembangan Isu Teori dan Aplikasi (Jakarta: Balai Pustaka, 1999), hlm. 298-304

${ }^{11}$ Soediarto, Memantapkan Sistem Pendidikan Nasional (Jakarta: Gramedia Widia Sarana, 1993), hal. 60-61

${ }^{12}$ Hamzah B. Uno, Op.Cit, hal. 67 
Kompetensi merupakan kemampuan dan kewenangan guru dalam melaksanakan profesi keguruannya, kompetensi guru dapat dibagi menjadi tiga bidang, yaitu:

a) Kompetensi bidang kognitif

Kompetensi ini adalah kemampuan intelektual seperti penguasaan mata pelajaran, disini meliputi beberapa bagian, yaitu: cara mengajar, belajar dan tingkah laku individu, bimbingan dan penyuluhan dikelas, menilai hasil belajar siswa, kemasyarakatan serta pengetahuan umum lainnya. ${ }^{13}$

b) Kompetensi bidang sikap

Kompetensi ini adalah kesiapan dan kesediaan guru terhadap berbagai hal yang berkenaan dengan tugas dan profesinya. Hal ini meliputi menghargai pekerjaan, mencintai dan memiliki perasaan senang terhadap mata pelajaran yang dibinanya, sikap toleransi terhadap mata pelajaran sesama teman, kemauan yang keras untuk meningkatkan hasil pekerjaannya. ${ }^{14}$

c) Kompetensi prilaku

Kompetensi ini adalah kemampuan guru dalam berbagai keterampilan dari prilaku, hal ini meliputi beberapa hal, yaitu: keterampilan mengajar, membimbing, menilai, menggunakan alat bantu, pengajaran bergaul, berkomunikasi, melaksanakan administarasi kelas, dan lain sebagainya. ${ }^{15}$ Perbedaan antara kompetensi kognitif dengan kompetensi ini adalah aspek teori atau pengetahuannya. Pada kompetensi ini yang ditampilkan adalah prektek dan keterampilan melaksanakannya.

\section{Upaya Pembentukan Kompetensi Guru dalam Mengelola Pembelajaran}

Dalam proses pendidikan, guru tidak hanya menjalankan fungsi alih ilmu pengetahuan, tetapi juga berfungsi untuk menanamkan nilai-nilai, guru adalah mengajar dan mendidik sekaligus. Dalam kaitan ini perlu disadari bahwa pada setiap mata pelajaran yang diajarkan harus membawa misi pendidikan dan kejujuran. Tugas guru agama disamping harus dapat memberikan pemahaman yang benar tentang ajaran agama, juga diharapkan dapat membangun jiwa dan karakter keberagamaan yang dibangun melalui pengajaran agama tersebut. ${ }^{16}$

Pelaksanaan pembelajaran di dalam kelas merupakan salah satu tugas utama guru. Pembelajaran diartikan sebagai kegiatan yang ditujukan untuk pembelajaran siswa, dalam proses pembelajaran masih sering di temui adanya kecenderungan meminimalkan keterampilan siswa. Dominasi guru dalam proses pembelajaran

\footnotetext{
${ }^{13}$ Ahmad Sabri, Strategi Belajar-mengajar dan Micro Teaching (Jakarta: Quantum Teaching, 2005), hal. 78

${ }^{14}$ Moh. Uzer Usman, Menjadi Guru Profesional (Bandung: PT Remaja Rosda Karya, 2006), hal. 21.

${ }^{15}$ Ibid., hal. 79

16 Marwan, Bunga Rampai (Pendidikan Agama Islam) (Jakarta: Dirotorat Jendral Kelembagaan Agama Islam,1999),hal. 21
} 
menyebabkan kecenderungan siswa lebih bersifat positif sehingga mereka lebih banyak menunggu sajian guru dari pada mencari dan menemukan sendiri pengetahuan keterampilan atau sikap yang mereka butuhkan.

Partisipasi siswa dalam kegiatan pembelajaran mencakup perhatian siswa terhadap penjelasan guru, kerjasamanya dengan teman sekelas dalam mengikuti kegiatan, kemampuan siswa mengemukakan pendapat, memberi kesempatan berpendapat kepada teman, mendengarkan dengan baik ketika teman berpendapat, memberi gagasan yang cenderung dan mengikuti kegiatan pembelajaran dengan senang dan semangat. Salah satu strategi pembelajaran aktif adalah strategi every one is teacher here. Strategi ini adalah salah satu strategi dalam model pembelajaran aktif. Strategi ini digunakan oleh pendidik dengan maksud meminta peserta didik untuk semuanya berperan menjadi narasumber terhadap semua temannya belajar di kelas.

Keterpaduan proses belajar mengajar siswa dalam proses mengajar guru tidak pernah terbentuk begitu saja, tanpa adanya pengaturan dan pemecahan sesama. Pengaturan dan pemecahan masalah ini harus diarahkan pada partisipasi siswa serta dapat menimbulkan minat belajar siswa.

Pembelajaran di sekolah dipengaruhi oleh guru, sistem dan lingkungan masyarakat serta keluarga. Guru agama merupakan salah satu komponen dengan kemampuan dan keterbatasan yang sering dimintai tanggung jawab berlebihan dan tidak profesional. Menurut Zakiah Drajat, sebagaimana yang dikutip oleh Marwan setiap orang yang akan melaksanakan tugas guru harus punya kepribadian. Disamping punya kepribadian yang sesuai dengan ajaran Islam, guru agama lebih dituntut lagi untuk mempunyai kepribadian guru. Guru adalah seorang yang seharusnya dicintai dan disegani oleh murid-muridnya. Penampilannya dalam mengajar harus menyakinkan dan tindak tanduknya akan ditiru dan diteladani, dalam melaksanakan tugasnya sebagai pendidik, ia harus tabah dan tahu cara memecahkan berbagai kesulitan dalam tugasnya sebagai pendidik, ia juga mau dan rela serta memecahkan berbagai masalah yang dihadapinya. Terutama masalah yang langsung berhubungan dengan proses belajarmengajar. ${ }^{17}$

Menjadi guru kreatif tidaklah terbentuk secara tiba-tiba, melainkan lahir dari proses pergumulan dengan ruang dan waktu seiring pengalaman yang dilaluinya. Guru yang kreatif artinya guru yang memiliki daya cipta, misalnya dalam menyiapkan metode, perangkat, media, dan muatan materi pembelajaran. Dari kreativitas guru tersebut akan menular pada siswa secara jangka pendek maupun panjang. Karena siswa sadar atau tidak cenderung belajar dari aktivitas dan kreativitas gurunya dalam proses

${ }^{17}$ Ibid., hal. 25 
pembelajaran. Kegiatan belajar yang kreatif, dapat merangsang semangat dan rasa penasaran siswa untuk belajar.

Guru perlu membuat keterbukaan komunikasi dengan siswanya. Sebelum pelajaran dimulai pada tahun ajaran baru, seyogyanya guru melakukan kontrak belajar dengan siswa. Guru memposisikan cara pandang bersama terhadap aktivitas di kelas sebagai relasi dan komunikasi di kelas adalah saling belajar. Kontrak belajar ini meliputi kenalan. Arah harapan dan pendapat atas pelajaran, serta membangun kesempatan dan kesepahaman kolektif antara guru dan siswa.

Membangun kreativitas guru membutuhkan proses, ia tidaklah lahir tiba-tiba, ada proses yang mengawalinya:

a. Belajar dari pengalaman mengajar.

b. Rasa cinta dan kasih sayang yang mendalam terhadap murid-muridnya agar mereka menjadi manusia ideal di masa yang akan datang.

c. Adanya tanggungjawab terhadap tugasnya.

d. Guru giat belajar untuk meningkatkan kualitas pengetahuan kepribadian dan keterampilannya yang berhubungan dengan tugas dan tanggung jawabnya sebagai guru. ${ }^{18}$

Dengan diberikannya kurikulum satuan tingkat pendidikan (KTSP), membuka ruang yang cukup luas bagi guru untuk melakukan penafsiran dan pengayaan materi, meskipun yang membuat soal semester tetap bukan dirinya sendiri. Ruang kreativitas gurupun perlu dirangsang dan difasilitasi oleh pihak manajemen sekolah dan pemerintah. Dalam hal-hal tertentu, kreativitas memerlukan bahan yang sedikit banyak membutuhkan dana. Pihak sekolah atau pemerintah perlu menyediakan dana dan penghargaan bagi guru-guru yang kreatif. Guru kreatif akan melahirkan siswa yang cerdas. Guru kreatif dan cerdas ini perlu banyak dilahirkan dengan penciptaan sistem, situasi dan kondisi yang merangsang pertumbuhan dan perkembangan guru yang kreatif dan cerdas. ${ }^{19}$

Kompetensi profesional guru menjadi faktor yang sangat menunjang peningkatan kualitas sekolah. Salah satu tugas guru adalah mengajar setiap guru memiliki kompetensi mengajar. Jika guru memiliki pemahaman dan penerapan secara teknis mengenai berbagai metode belajar mengajar serta hubungannya dengan belajar. Kompetensi guru akan membawa guru dapat memilih cara terbaik yang dapat dilakukan supaya kegiatan pembelajaran dapat berjalan baik dan meningkatan potensi siswa. Guru merupakan komponen yang paling berpengaruh terhadap terciptanya proses dan hasil pendidikan yang berkualitas. Oleh karena itu, upaya perbaikan apapun yang dilakukan 2000), hal. 135

18 Saleh, Abdul Rahman, Pendidikan Agama dan Keagamaan (Jakarta: PT. Kemawindu Pancaperkasa,

${ }^{19}$ Martinis, Op-Cit, hal. 32 
untuk meningkatkan kualitas pendidikan tidak akan memberikan sumbangan yang signifikan tanpa didukung oleh guru yang profesional dan berkualitas. Peningkatan efisiensi diperoleh melalui keleluasaan mengelola sumber daya yang ada, partisipasi masyarakat dan penyederhanaan birokrasi. Peningkatan mutu diperoleh melalui partisipasi orang tua, kelenturan pengelolaan sekolah, peningkatan profesionalisme guru, adanya hadiah dan hukuman sebagai kontrol serta hal lain yang dapat menumbuh kembangkan suasana kondusif. Pemerataan pendidikan tampak pada tumbuhnya partisipasi masyarakat terutama yang mampu dan peduli, sementara ing kurang mampu akan menjadi tanggungjawab pemerintah. ${ }^{20}$

\section{HASIL PENELITIAN}

\section{Kompetensi Guru dalam Mengelola Pembelajaran di Kelas}

Gambaran kompetensi guru dalam mengelola pembelajaran di kelas, akan diuraikan secara sistematis yaitu:

a. Gambaran perencanaan pembelajaran

Berdasarkan hasil wawancara dengan guru Al-Qur'an Hadist, bahwa pembuatan satuan pembelajaran sebelum proses pembelajaran belum maksimal.

Hasil wawancara dengan guru Al-Qur'an Hadiśt sebelum mengajar selalu mempersiapkan dan membuat satuan pembelajaran walaupun masih bayak kekurangan. ${ }^{21}$

b. Gambaran perumusan tujuan pembelajaran Dari dari hasil wawancara dapat diketahui bahwa guru di Pon-pes Darul Mursyidi sudah mampu merumuskan tujuan pembelajaran.

Berdasarkan uraian di atas dihubungkan dengan hasil wawancara dengan guru mata pelajaran Al-Qur'an Hadiśt menyatakan bahwa proses pembelajaran tidak bisa dilaksanakan dengan baik tanpa adanya perumusan tujuan pembelajaran. ${ }^{22}$

c. Gambaran persiapan bahan pelajaran.

Selanjutnya dalam mempersiapkan bahan pelajaran guru selalu mempersiapkan bahan pembelajaran sebelum mengajar.

Berdasarkan uraian di atas dan dihubungkan dengan hasil wawancara dengan guru Aqidah Akhlak menyatakan bahwa mempersiapkan bahan pelajaran sebelum memulai proses belajar mengajar maka pemberlajaran akan bisa terarah dan tujuan pembelajaranakan tercapai dengan baik. ${ }^{23}$

\footnotetext{
${ }^{20} \mathrm{Ibid}$, hal. 78

${ }^{21}$ Bapak Zubeir /Guru al-Qur' an Hadiśt, Wawancara 1 April 2015

22 Bapak Zubeir /Guru al-Qur'an Hadiś Wawancara pada tanggal 1 April 2015

${ }^{23} \mathrm{Ibu}$ Yetta /Guru Aqidah Akhlak Wawancara pada tanggal 2 April 2015
} 
d. Gambaran pengadaan appersepsi pada kegiatan awal pembelajaran. Selanjutnya mengadakan appersepsi pada kegiatan awal pembelajaran di Pon-pes Darul Mursyidi oleh guru, dari hasil wawancara dapat diketahui bahwa mengadakan appersepsi pada kegiatan awal kegiatan, terlihat tidak terlaksana dengan baik. Berdasarkan observasi guru masih belum maksimal dalam mengadakan appersepsi, sehingga siswa kurang dalam menguasai bahan pelajaran yang telah disampaikan guru, ${ }^{24}$ dan dalam pemberian motivasi masih sangat lemah sehingga banyak siswa yang kurang berminat dalam mengikuti pembelajaran.

e. Hasil wawancara dengan guru menyatakan bahwa mengadakan pretest pada kegiatan awal proses belajar-mengajar masih jarang dilaksanakan hal ini karena seringnya keterlambatan masuk kelas. Pretest adalah pertanyaan-pertanyaan yang diberikan guru pada saat awal pelajaran, sebelum masuk pelajaran yang akan datang. Pretest sangat baik dikerjakan untuk mengetahui kemampuan siswa-siswi dalam menguasai pelajaran yang telah lalu dan dikaitkan dengan pelajaran yang akan di sajikan dan untuk mengulang kembali pelajaran yang telah lalu.

f. Penggunaan metode dalam proses pembelajaran di Pon-pes Darul Mursyidi dapat diketahui bahwa guru selalu menggunakan metode dalam proses belajar-mengajar walaupun masih belum maksimal.

Berdasarkan uraian di atas dan bila dihubungkan dengan hasil wawancara dengan guru mata pelajaran Al-Qur'an Hadiśt dalam menyampaikan bahan pelajaran selalu menggunakan matode, “Bagaimana menyampaikan bahan pelajaran tanpa menggunakan metode, paling tidak metode ceramah". ${ }^{25}$ Metode merupakan cara guru menyampaikan pelajaran kepada siswa, tanpa metode yang sesuai maka proses belajar-mengajar tidak bisa di capai dengan afektif, efisien dan menyenangkan.

7. Penggunaan media dalam proses pembelajaran dapat diketahui bahwa dalam proses belajar mengajar berkategori kurang. Dengan demikian dapat diketahui bahwa dalam menggunakan media dalam proses pembelajaran dikategorikan lemah dan kurang.

Dari uraian di atas bila dihubungkan dengan hasil wawancara bahwa menggunakan media dalam proses pembelajaran menggalami kendala, seperti kurangnya alat-alat peraga, dan operasional saat proses belajar mengajar, ${ }^{26}$ bahkan berdasarkan observasi peneliti terlihat ketika berlangsunya proses belajar-mengajar minimnya sarana-prasarana dalam belajar seperti halnya dalam penggunaan media. ${ }^{27}$

\footnotetext{
${ }^{24}$ Bapak Zubeir /Guru al-Qur'an Hadiś observasi Tanggal 1 April 2015.

${ }^{25}$ Bapak Zubeir /Guru al-Qur'an Hadiś Wawancara Tanggal 1 April 2015.

26 Ibu Supiani /Guru TIK, Wawancara tanggal 2 April 2015.

27 Ibu Supiani /Guru TIK, Wawancara tanggal 2 April 2015.
} 
8. Tata tertib siswa, fasilitas belajar, kompetensi guru dalam mengelola pembelajaran. Dari hasil wawancara dapat disimpulkan bahwa kompetensi guru dalam mengelola pembelajaran dilihat dari pengetahuan siswa, fasilitas belajar sudah lebih baik.

Berdasarkan observasi, peneliti melihat bahwa guru dalam mengelola kelas masih terdapat kendala walaupun sudah lebih baik dari sebelumnya, karena masih ada guru yang harus lebih bayak mengikuti seminar dan pelatihan pendidikan.28

9. Gambaran pelaksanaan post test, Selanjutnya kompetensi guru dalam mengelola pembelajaran melalui post test, dari wawancara dapat diketahui kompetensi guru dalam mengelola pembelajaran melalui pelaksanaan post test pada kegiatan akhir proses pembelajaran, masih belum maksimal. Uraian di atas, bila dihubungkan dengan hasil wawancara dengan guru mata pelajaran Al-Qur'an Hadiśt menyatakan bahwa post test tidak terlalu sering dilaksanakan karena adanya kendala kekurangan waktu. ${ }^{29}$

10. Memberikan kesimpulan dalam pelajaran, dari hasil wawancara dapat disimpulkan bahwa kompetensi guru dalam mengelola pembelajaran sudah maksimal. hasil wawancara dengan guru mata pelajaran Al-Qur'an Hadiśt menyatakan bahwa sebelum menutup pelajaran terlebih dahulu menyimpulkan pelajaran. ${ }^{30}$ Menyimpulkan suatu pelajaran adalah hal yang sangat penting agar siswa bisa lebih memahami isi materi belajaran.

11. Tindak lanjut pada kegiatan akhir pembelajaran, hasil wawancara bahwa kompetensi guru dalam mengelola pembelajaran melalui pemberian tindak lanjut pada kegiatan akhir proses pembelajaran, jarang dilaksanakan. Dengan demikian dapat di ketahui bahwa guru kurang dalam hal memberikan tindak lanjut dari materi pembelajaran.

Hasil wawancara dengan guru Al-Qur'an Hadiśt menyatakan bahwa memberikan tindak lanjut pada kegiatan akhir pembelajaran masih sangat jarang dilakukan, karena sarana dan prasarana di pondok pesantren yang masih kurang mendukung.

2. Upaya Guru dalam Melaksanakan dan Mengelola Pembelajaran di Pon-pes Darul Mursyidi.

Dari hasil wawancara yang dilakukan peneliti tentang upaya pembentukan kompetensi guru dalam mengelola pembelajaran bersama kepala Sekolah dan guru di Pon-pes Darul Mursyidi.

Adapun hasil wawanacara tersebut adalah sebagai berikut:

\footnotetext{
${ }^{28}$ Bapak Azzam /Guru SKI, Observasi Tanggal 2 April 2015

${ }^{29}$ Bapak Zubeir /Guru Al-Qur'an Hadiś, Wawancara Tanggal 1 April 2015

${ }^{30}$ Bapak Zubeir /Guru al-Qur'an Hadiś, Wawancara Tanggal 1 April 2015.
} 
a. Latar belakang pendidikan guru adalah sangat menunjang tentang kompetensi mengajar dan diharapkan kepada para guru agar melanjtkan pendidikan ke jenjang yang lebih tinggi.

b. Guru selalu menjadikan pengalaman mengajar sebagai pelajaran untuk menyempurnakan kekurangannya. ${ }^{31}$

c. Penggunaan media yang masih terdapat banyak kendala, hal ini disebebabkan karena kurangnya dana operasional, alat-alat yang dibutuhkan untuk menunjang keberhasilan pembelajaran, walaupun demikian guru masih berupaya untuk memanfaatkan sarana yang ada di pesantren dalam menunjang proses pembelajaran

d. Komunikasi guru dan siswa yang ada di Pon-pes Darul Mursyidi harus tetap terjaga dengan baik, karena dengan komunikasi yang baik dapat membantu keberhasilan proses belajar-mengajar guru. ${ }^{32}$

e. Mengikuti pelatihan kependidikan, memberikan peluang untuk menambah wawasan dan keterampilan kepada guru. ${ }^{33}$

f. Mempersiapkan guru tersertifikasi, dan sudah ada 7 orang guru yang sudah sertifikasi di ponpes darul mursyidi

\section{PENUTUP}

Kompetensi guru dalam melaksanakan dan mengelola pembelajaran di Pon-pes Darul Mursyidi, sudah mulai baik walaupun masih bayak kendala, semua proses perencanaan dan pelaksanaan pembelajaran sudah mulai maksimal diterapkan oleh guru di Ponpes Darul Mursyidi. Bahwa upaya pembentukan kompetensi guru adalah : menumbuhkan kreatifitas guru, mengikuti penataran loka karya, Latar belakang pendidikan guru dengan menyarankan guru melanjutkan pendidikan ke jenjang yang lebih tinggi, mengikuti seminar atau pelatihan, mengikuti program-program yang di upayakan pihak sekolah, membaca buku yang relevan, mengikuti workshop dan diklat yang di selenggarakan pihak pemerintah maupun swasta dan melakukan sharing atau dialog dengan orang yang lebih berpengalaman untuk menambah wawasan. Kepada semua guru agar betul-betul berupaya untuk meningkatkan kompetensinya dalam pengelolaan pembelajaran untuk menunjang tercapainya tujuan pembelajaran yang baik. Diharapkan kepada pihak sekolah agar selalu berupaya untuk meningkatkan kompetensi guru, dan memfasilitasi guru dalam mengembangkan keahlian di bidang nya masing-masing.

\footnotetext{
${ }^{31}$ Bapak Zubeir/Guru Al-Qur'an Hadiś, Wawancara Tanggal 1 April 2015.

32 Bapak Zubeir /Guru al-Qur'an Hadiś, Wawancara Tanggal 1 April 2015

${ }^{33}$ Bapak Ridwan Rambe Kepala Sekolah Aliyah Wawancara, Tanggal 2 April 2015.
} 


\section{DAFTAR PUSTAKA}

B Uno, H. Hamzah, Profesi Kependidikan, Jakarta: PT Bumi Aksara, 2008.

Djamarah, Bahri, Syaiful, Prestasi Belajar dan Kompetensi Mengajar , Surabaya: Usaha Nasional, 1991.

Marwan, Bunga Rampai (Pendidikan Agana Islam), Jakarta: Diroktorat Jendral Kelembagaan Agama Islam, 1999 .

Musfah, Jejen, Peningkatan Kompetensi Guru Jakarta: Kencana Prenada Media Group, 2012

Nasution, Mustanir /Kepala Sekolah, Wawancara Tanggal 6 Oktober 2014.

Rahman, Abdul, Saleh, , Pendidikan Agama dan Keagamaan, Jakarta: PT. Gemawindu Pancaperkasa, 2000 .

Sabri, Alisuf, Mimbar Agama dan Budaya,Cet. Ke-I, Jakarta: Pusat Penelitian dan Pengabdian pada Masyarakat IAIN, 1992.

Sagala, Syaiful, konsep dan makna pembelajaeran Bandung: Alfabeta, 2012

Satori, Djam'an, H., Sunaryo Karta Dinata dkk, Profesi Keguruan I, Jakarta: Universitas Terbuka, 2002.

Soedianto, Memantapkan Sistem Pendidikan Nasional, Jakarta: Gramedia Widiasarana, 1993.

Sarbi, Ahmad, Strategi Belajar-Mengajar dan Micro Teaching, Jakarta: Quantum Teaching, 2000.

Suryadi, Ace, Pendidikan Investasi SDM dan Pembangunan Isu Teori dan Aplikasi, Jakarta: Balai Pustaka, 1999.

Undang-Undang Republik Indonesia, Nomor. 14 Tahun 2005, Tentang Guru dan Dosen, Bab I Pasal I Ayat 10 Jakarta: Sinar Grafika, 2006

Usman, Uzer, Moh., Menjadi Guru Profesional, Bandung: PT Remaja Rosda Karya, 2006.

Yamin, Martinis, Profesionalliasi Guru dan Implementasi KTSP, Jakarta: PT Raja Grafindo Persada, 2001. 